\title{
Filtek $^{\mathrm{TM}}$ Silorane and Filtek ${ }^{\mathrm{TM}}$ Supreme XT Resins: Tissue Reaction After Subcutaneous Implantation in Isogenic Mice
}

\author{
Esther RUIZ DE CASTAÑEDA ${ }^{1}$ \\ Léa A. B. SILVA ${ }^{2}$ \\ Patrícia GATON-HERNÁNDEZ ${ }^{3}$ \\ Alberto CONSOLARO 4 \\ Encarnación Gonzalez RODRIGUEZ ${ }^{5}$ \\ Raquel A. B. SILVA ${ }^{2}$ \\ Alexandra M. QUEIROZ ${ }^{2}$ \\ Paulo NELSON-FILHO ${ }^{2}$
}

\author{
${ }^{1}$ La Societad Catalana d'odontoestomatologia de l'Acadèmia de Ciències Mèdiques I de la Salut \\ de Catalunya I de Balears, Barcelona, Spain \\ ${ }^{2}$ Department of Pediatric Clinics, Preventive and Community Dentistry, Ribeirão Preto Dental School, \\ USP - University of São Paulo, Ribeirão Preto, SP, Brazil \\ ${ }^{3}$ University of Barcelona, Barcelona, Spain \\ ${ }^{4}$ Pediatric Dentistry Postgraduate Program, Department of Pediatric Clinics, Preventive and Community Dentistry, \\ Ribeirão Preto Dental School, USP - University of São Paulo, Ribeirão Preto, SP, Brazil \\ ${ }^{5}$ Facultad Odontología, University of Granada, Granada, Spain
}

\begin{abstract}
The aim of this study was to evaluate the tissue compatibility of a silorane-based resin system (Filtek ${ }^{\mathrm{TM}}$ Silorane) and a methacrylatebased nanoparticle resin (Filtek ${ }^{\mathrm{TM}}$ Supreme XT) after implantation in the subcutaneous connective tissue of isogenic mice. One hundred and thirty five male isogenic BALB/c mice were randomly assigned to 12 experimental and 3 control groups, according to the implanted material and the experimental period of 7,21 and 63 days. At the end of each period, the animals were killed and the tubes with the surrounding tissues were removed and processed for microscopic analysis. Samples were subjected to a descriptive and a semi-quantitative analyses using a 4-point scoring system (0-3) to evaluate the collagen fiber formation and inflammatory infiltrate. Data were statistically analyzed using the Kruskal Wallis test $(\alpha=0.05)$. The results showed that there was no significant difference between the experimental and control groups considering the three evaluation periods $(\mathrm{p}>0.05)$. The silorane-based and the methacrylate-based nanoparticle resins presented similar tissue response to that of the empty tube (control group) after subcutaneous implantation in isogenic mice.
\end{abstract}

Key Words: subcutaneous tissue, tissue reaction, nanocomposite, nanometric particles, mathacrylate-based resin, silorane-based resin.

\section{INTRODUCTION}

Methacrylate-based composite resins release uncured monomers to the tissues (1), which have been associated with hypersensitivity and cytotoxicity (2), genotoxicity (3), estrogenicity (4), and immune system alterations (5).

Cell culture studies have demonstrated that methacrylate and dimethacrylate monomers, commonly used in the restorative polymeric technology, may affect the recruitment of leukocytes in inflammation sites by decreasing the expression of intercellular adhesion molecules and inducing enzymatic activity and expression of growth factors and cellular cytokines (6). In addition, resin monomers suppress the mitochondrial activity of macrophages and alter their inflammatory responses $(4,7)$.

In this way, reactive components released from conventional composite resins, such as unreacted monomers (1) and oxidation products, may induce toxicity or inflammatory tissue reactions (8). Adhesive

Correspondence: Prof. Dr. Paulo Nelson-Filho, Departamento de Clínica Infantil, Odontologia Preventiva e Social, Faculdade de Odontologia de Ribeirão Preto, USP, Avenida do Café, S/N, 14040-904 Ribeirão Preto, SP, Brasil. Tel: +55-16-3602-4099. Fax: +55-16-3633-0999. e-mail: nelson@forp.usp.br 
system components may also unchain an unfavorable tissue reaction, avoiding the occurrence of healing (9).

In the last few years, methacrylate-based resins with modifications in their composition and structure, such as Filtek ${ }^{\mathrm{TM}}$ Supreme XT (3M ESPE, St. Paul, MN, USA) have been developed. This resin is a nanocomposite that contains only nanomeric particles and nanoclusters as inorganic fillers. The nanomeric particles are monodispersed, nonagglomerated silica particles, while the nanoclusters are spheroidal agglomerates consisting of nano-sized silica and zirconia particles. The micron-sized porous cluster is infiltrated with silane coupling agents to allow chemical bonding with the organic matrix (10). However, though adequate physical properties have been attributed to these resins (e.g.: improved surface polishing) (10), they have shown toxic effects in cell cultures (1).

On the otherhand, theoccurrence of polymerization shrinkage and the release of chemical products from methacrylate-based systems have led to the development of silorane-based composite resins, such as the resin Filtek $^{\mathrm{TM}}$ Silorane (3M ESPE). The silorane matrix is formed by the cationic ring-opening polymerization of the silorane monomers. The silorane molecule represents a hybrid that is made of both siloxane and oxirane structural moieties (11). The silorane technology has afforded a highly hydrophobic restorative material with reduced polymerization shrinkage, more balanced volumetric stress, high ambient light stability (11), and insolubility in biological fluids (12).

Although recent studies have evaluated physicochemical properties of silorane-based resins $(13,14)$, research regarding their biological effects, mostly based on in vitro cell culture studies $(1,3)$, is quite limited. To date, there is no study evaluating the in vivo compatibility of these new restorative systems with the connective tissue. The present study evaluated the tissue compatibility of a silorane-based resin system (Filtek ${ }^{\mathrm{TM}}$ Silorane) and a methacrylate-based nanoparticle resin (Filtek ${ }^{\mathrm{TM}}$ Supreme XT) after implantation in the subcutaneous connective tissue of isogenic mice.

\section{MATERIAL AND METHODS}

All experiments were conducted according to the guidelines of the Animal Care and Use Committee of the University of São Paulo, Ribeirão Preto Campus, Brazil. The study design and histological parameters for tissue reaction evaluation were in accordance with the
ISO 10993-6 standard (15).

One hundred and thirty five male isogenic $\mathrm{BALB} / \mathrm{c}$ mice aged 6-8 weeks and weighing 15 to $20 \mathrm{~g}$ were obtained from the Laboratory Animal Care Facility of the Medical School of Ribeirão Preto, University of São Paulo, Brazil, and were randomly assigned to 12 experimental ( $\mathrm{n}=10$ animals/group) and 3 control groups ( $\mathrm{n}=5$ animals/group). Each animal received one polyethylene tube implant $(10 \mathrm{~mm}$ long x $1 \mathrm{~mm}$ internal diameter) on the dorsal region. All tubes had their ends closed by using sterile heated clinical tweezers, and were then sterilized with ethylene oxide, and filled with the materials under aseptic conditions in a laminar flow chamber immediately prior to use and implantation as follows: Group I, II and III: Filtek ${ }^{\mathrm{TM}}$ Silorane at 7, 21 and 63 days, respectively; Groups IV, V and VI: Filtek ${ }^{\mathrm{TM}}$ Silorane adhesive bond at 7, 21 and 63 days; Groups VII, VIII and IX: Filtek ${ }^{\mathrm{TM}}$ Silorane primer at 7, 21 and 63 days; Groups X, XI and XII: Filtek ${ }^{\mathrm{TM}}$ Supreme XT at 7 , 21 and 63 days; and Groups XIII, XIV and XV (control groups): empty tube at 7,21 and 63 days, respectively.

Before tube implantation, the animals were anaesthetized with an intraperitoneal injection of $10 \%$ chloral hydrate $(1 \mathrm{~mL} / 100 \mathrm{~g}$ body weight), and had the dorsal region shaved and cleaned with a $1 \%$ chlorhexidine solution. A 1-cm-wide incision was made on the dorsal region followed by tissue divulsion with Kelly forceps, and the tube was inserted into the connective tissue and the skin borders were closed with 4-0 silk sutures (Vicryl; Johnson \& Johnson: Ethicon Inc., New Brunswick, NJ, USA). The surgery was performed under aseptic conditions to minimize the trauma to the implant area. The animals were kept with free access to standard chow and water during the experimental periods and were periodically observed for local, systemic and behavioral abnormalities.

At the end of each evaluation period, the animals of each experimental and control groups were anesthetized for careful removal of the implant together with the surrounding tissues (skin and subcutaneous connective tissue). Then, they were killed by anesthetic overdose. The removed tissues were fixed in $10 \%$ buffered formalin solution for $48 \mathrm{~h}$ and subjected to routine processing for histological analysis. Serial 5 - $\mu$ m-thick sections were made parallel to the long axis of the tube and stained with hematoxylin and eosin. The specimens were examined by a trained pathologist with a light binocular microscope (Olympus, Tokyo, Japan) at 4, 10, 40, and $\times 100$ magnifications. Descriptive (qualitative) and semi- 
quantitative microscopic analyses of tissue reaction (16) to the tested materials and the empty tubes at the different experimental periods were done. In the semi-quantitative analysis, a four-point (0-3) scoring system was used to evaluate the number and density of collagen fibers within the tissue surrounding to the tested material and the concentration of polymorphonuclear neutrophils.

- Collagen fiber formation: score $0=$ absent; score 1 = mild: individual collagen fiber arrangement resembling a normal connective tissue, permeated by negative spaces indicative of non-fibrous components of the extracellular matrix; score $2=$ moderate: areas with individual collagen fibers alternated with areas of eosinophilic extracellular matrix without typical linear and undulate formations; and score 3 = intense: collagen fibers merged within an eosinophilic extracellular matrix without the typical linear and undulate formations, not allowing to distinguish the individual fibers.

- Inflammatory infiltrate: score $0=$ absent; score $1=$ mild ( 1 to $10 \mathrm{PMN})$; score $2=$ moderate $(11$ to 20 $\mathrm{PMN})$; and score $3=$ intense ( $>21 \mathrm{PMN})$.

Higher scores related to collagen fibers formation, and inflammatory infiltrate, represented the worst tissue compatibility of the materials. The results from the semiquantitative analysis were analyzed statistically by the nonparametric Kruskal Wallis test at 5\% significance level using the GraphPad 5.0 statistical software (GraphPad Software Inc., San Diego, CA, USA).

\section{RESULTS}

\section{7 days}

Tissue reaction was predominantly formed by young, ovoid, fusiform fibroblasts with slightly organized thin collagen fiber bundles. Macrophages were found between the fibroblasts. PMN and occasional eosinophils were diffusively distributed in the tissue. There were also a large number of newly formed blood vessels. Multinucleated foreign body giant cells (FBGC), usually with 4 to 5 nuclei each, were found at the interface between the reactionary tissue and the material (Figs. $1 \mathrm{~A}, \mathrm{~B}$ and $2 \mathrm{~A}$ ). The thickness of the reactionary tissue ranged from 10 to 30 cells.

\section{1 days}

It was observed slightly more collagen fiber formation than in the 7-day period with more well defined collagen fiber bundles with capsular organization. Young fibroblasts and macrophages were present. The vascular component was moderately present (Figs. 1C,D, and 2B). There was a discrete and diffuse PMN infiltrate and a few eosinophils. The thickness of the tissue reaction ranged from 10 to 20 cells. Multinucleated FBGC at the tissue/material interface had 4 to 5 nuclei each. In one specimen of group V (Filtek ${ }^{\mathrm{TM}}$ Silorane adhesive bond) there was a well organized foreign body granuloma surrounding a material fragment that extruded to the circumjacent tissue.

\section{3 days}

It was observed a thin and well organized with a fibrous capsule with well defined margins of collagen fiber bundles permeated by predominantly mature fusiform and thin fibroblasts with well condensed nuclei. The vascular component decreased and only some vessels persisted as part of the tissue structure. Several specimens did not show PMN or eosinophil infiltrate. When present, the infiltrate was mild and diffuse. At the at the reactionary tissue/material interface there were a few multinucleated FBGC with 3 to 4 nuclei each (Figs. $1 \mathrm{E}, \mathrm{F}$, and $2 \mathrm{C}$ ). The thickness of the tissue reaction ranged from 5 to 15 cells.

In the semi-quantitative microscopic analysis there was no statistically significant difference $(p>0.05)$ among the groups at any of the periods according to the mean scores values obtained after analysis of collagen fiber formation and inflammatory infiltrate (Figs. 3 and 4).

\section{DISCUSSION}

Although the characterization of tissue response is a key factor to substantiate the clinical use of new dental materials, no study has yet evaluated this aspect with Filtek ${ }^{\mathrm{TM}}$ Supreme XT. In the present study, this material presented compatibility with the subcutaneous connective tissue of mice, since the inflammatory response at all evaluation periods was similar the one unchained by the group control (empty tube), exhibiting a small number of PMN, few macrophages and fibrous capsule formation. This is possibly because Filtek ${ }^{\mathrm{TM}}$ Supreme XT is composed of nanoparticles and nanoclusters (10), which may reduce the interstitial space and, consequently, the amount of organic matrix capable of releasing methacrylates, thus causing less tissue 
irritation than conventional methacrylate-based resins.

The biological response to dental restorative polymer composites is mediated by the release of uncured residual monomers. Methacrylate-free resin composite formulations have claimed to reduce unpolymerized residual mass. Filtek ${ }^{\mathrm{TM}}$ Silorane is one of these materials, based on an innovative monomer system that combines important characteristics, such as low polymerization shrinkage and high hydrophobicity
(11). Siloranes are stable materials that are insoluble in different biological fluids (12) and have little water sorption and low diffusion coefficient compared to conventional methacrylate-based resins. According to Hahel et al. (13), the macro-, micro- and nanomechanical properties of silorane-based resins are comparable to those of methacrylate-based resins.

However, only few cell culture studies have investigated biological properties of silorane-based
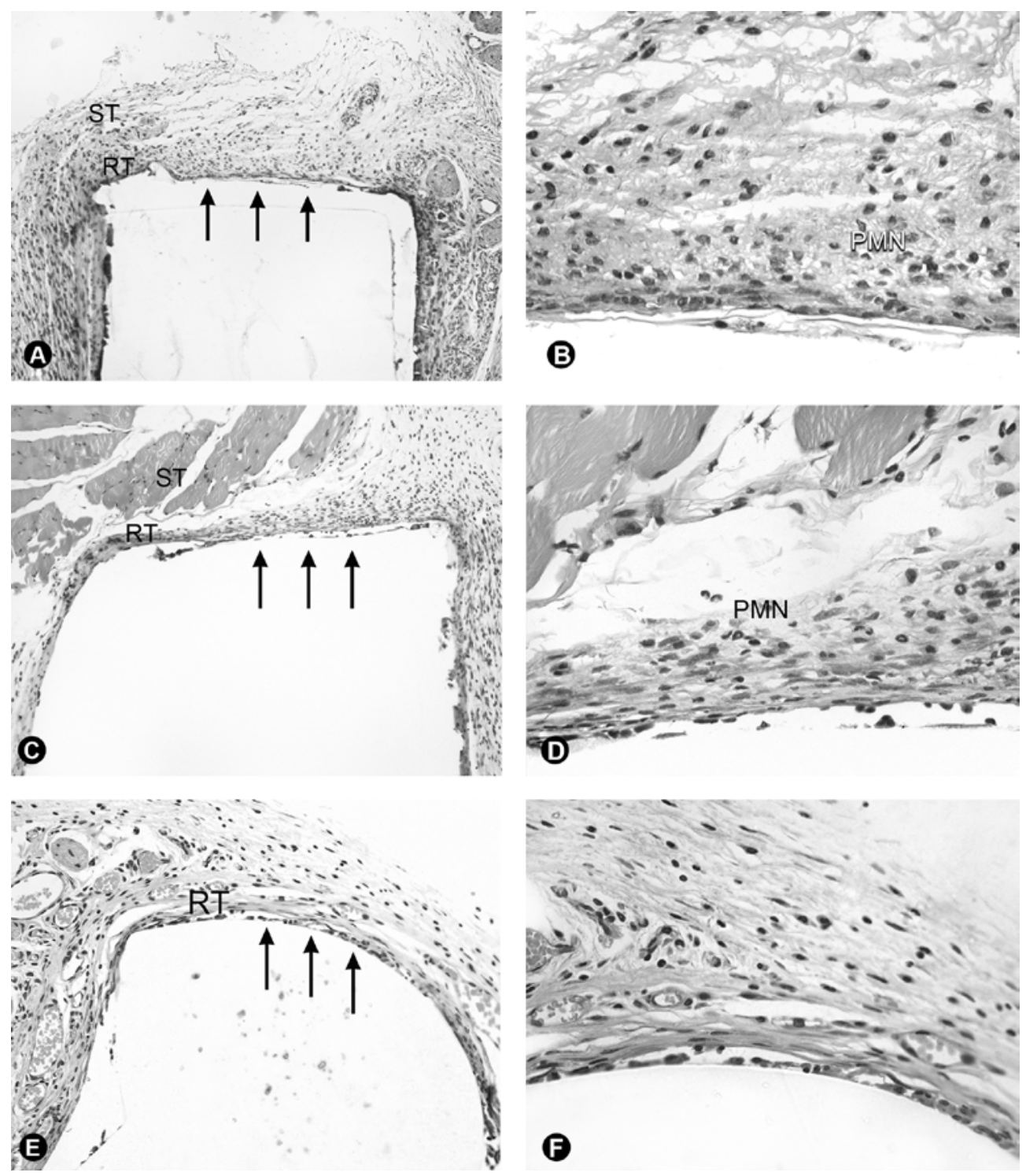

Figure 1. Microscopic aspects of the tissue reaction (RT) at 7 days (A, B), 21 days (C, D) and 63 days (E, F) at the interface (arrows) between the implanted materials and the surrounding tissue (ST). The intensity of collagen fiber formation increased and the presence of polymorphonuclear neutrophils (PMN) decreased gradually with time. (A, B = group IV - bonding agent of Filtek ${ }^{\mathrm{TM}}$ Silorane at 7 days, $\mathrm{HE} \times 25$ and $\times 100$ magnification; $\mathrm{C}, \mathrm{D}=$ group II - Filtek $^{\mathrm{TM}}$ Silorane at 21 days, $\mathrm{HE} \times 25$ and $\times 100$ magnification; $\mathrm{E}, \mathrm{F}=$ group XII - Filtek ${ }^{\text {TM }}$ Supreme XT at 63 days, $\mathrm{HE} \times 25$ and $\times 100$ magnification). 
resins, showing no cytotoxic effects and low mutagenic potentials (17). Another study (1) evaluating the in vitro cytotoxicity of different resins in Balb/c $3 \mathrm{~T} 3$ mouse fibroblast cell cultures during 8 weeks found that the methacrylate-free resin Hermes, precursor of Filtek ${ }^{\mathrm{TM}}$
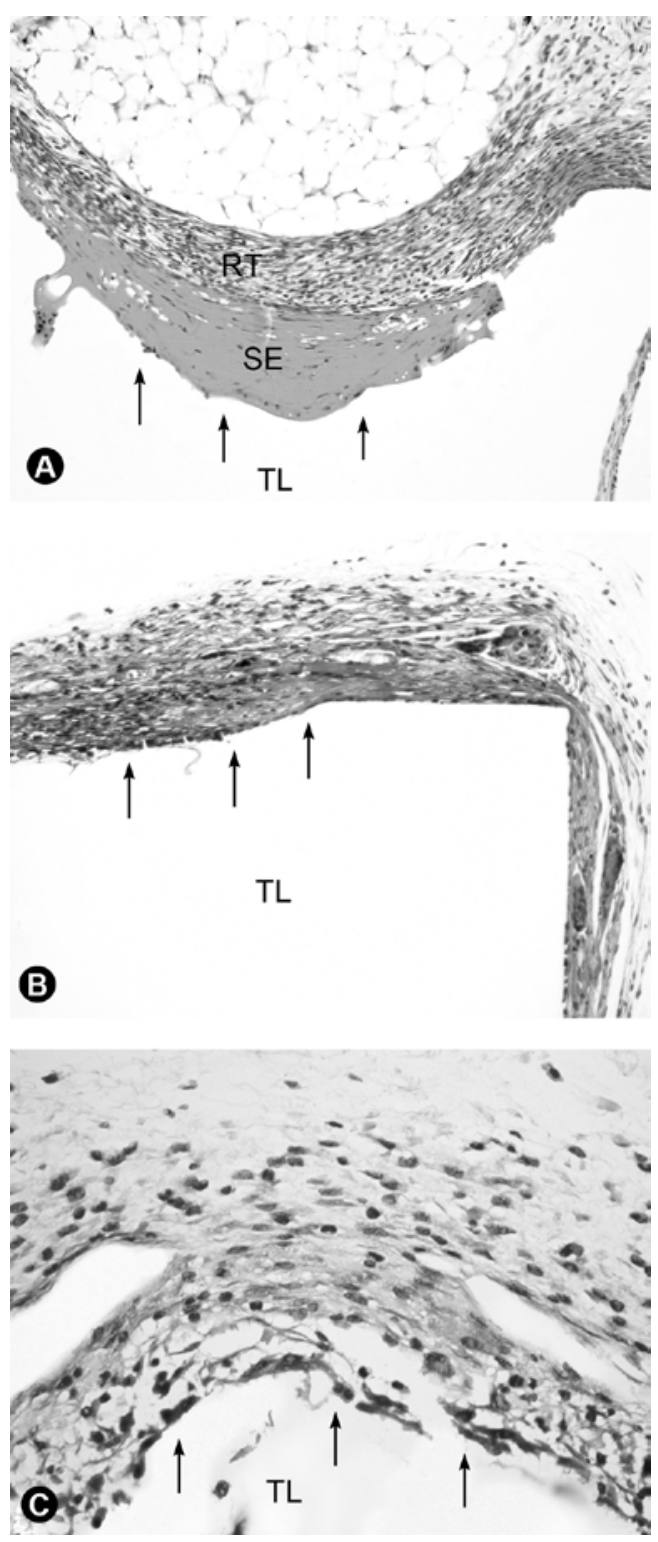

Figure 2. Microscopic aspects of the reactionary tissue (RT) at 7 days (A), 21 days (B) and 63 days (C) at the empty tube (control group) end (arrows) in contact with the surrounding tissue. It can be observed that a serofibrinous exudate (SE) was formed at the tube lumen interface (TL) in the 7-day period. It can also be noticed that the presence of polymorphonuclear neutrophils decreased gradually with time (A, B and C $=\mathrm{HE}$, $\times 24$ magnification).
Silorane, presented cytotoxicity similar to the control group (Teflon), which is consistent with the findings of the present study. However, to date, there is no published study evaluating the tissue response to the Filtek $^{\mathrm{TM}}$ Silorane. In the present in vivo study, this resin and its components alone (primer and adhesive bond) induced low-intensity connective tissue reactions. These responses were similar to those triggered by the empty tube (control) at all evaluation periods, demonstrating the

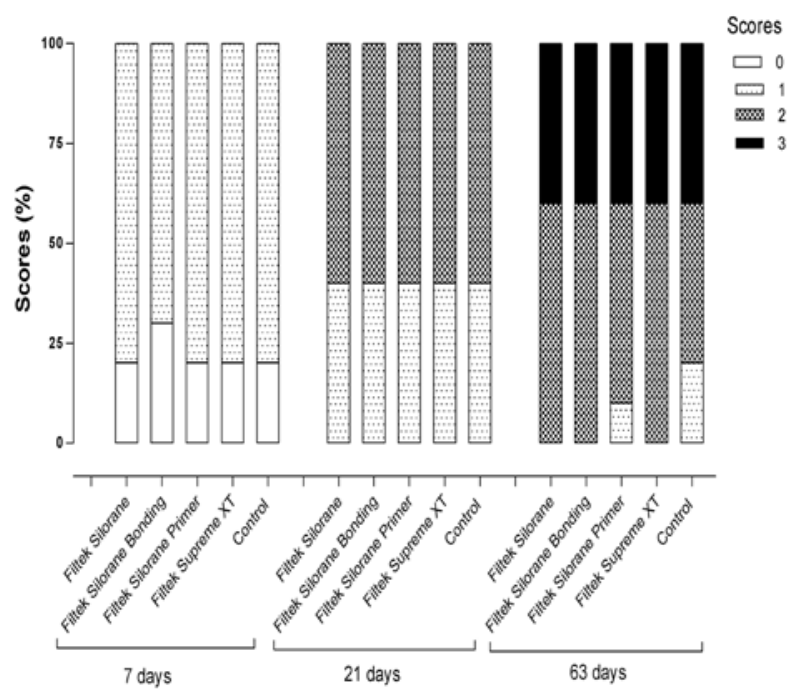

Figure 3. Score distribution of the experimental and control groups regarding collagen fiber formation.

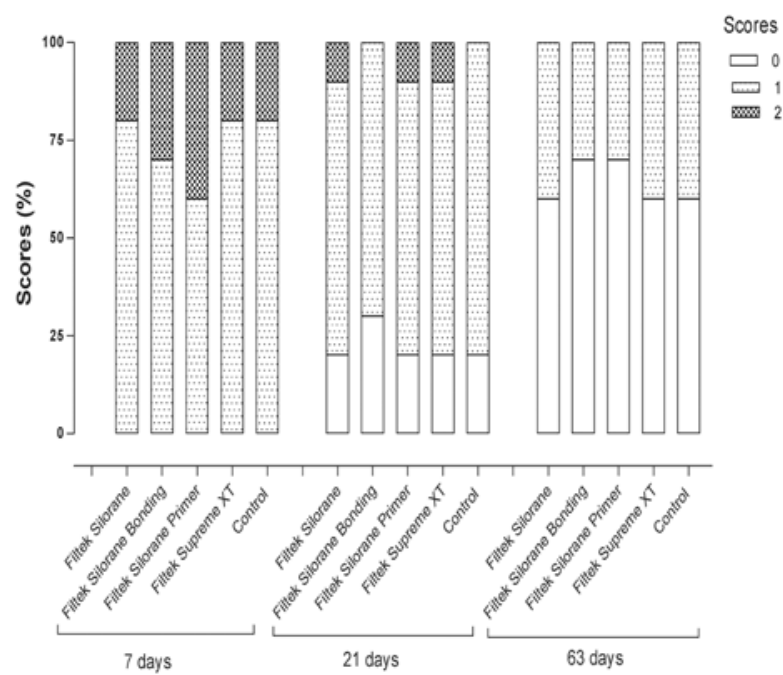

Figure 4. Score distribution of the experimental and control groups regarding inflammatory infiltrate. 
low capacity of this material inducing unfavorable tissue reactions, and it was in agreement with Brackett et al. (1) that showed that materials with new polymerization modes are promising for reducing the release of uncured components and, consequently, their cytotoxicity.

Under the tested conditions, the siloranebased (Filtek ${ }^{\mathrm{TM}}$ Silorane) and the methacrylate-based nanoparticle (Filtek ${ }^{\mathrm{TM}}$ Supreme XT) resins presented tissue response similar to that of the control group (empty tube) after implantation in the subcutaneous connective tissue of isogenic mice. The results of the present study may have great significance because, in addition to its claimed low polymerization shrinkage, Filtek $^{\mathrm{TM}}$ Silorane showed tissue compatibility in vivo. Further research is needed to support the clinical use of these new materials.

\section{RESUMO}

O objetivo do presente estudo foi avaliar a compatibilidade tecidual de um sistema resinoso à base de silorane (Filtek ${ }^{\mathrm{TM}}$ Silorane) e de uma resina nanoparticulada à base de metacrilato (Filtek ${ }^{\mathrm{TM}}$ Supreme XT), após implantação no tecido conjuntivo subcutâneo de camundongos isogênicos. Um total de 135 camundongos isogênicos BALB/c machos foram randomicamente divididos em 12 grupos experimentais e em 3 grupos controles, de acordo com o material implantado e com o período experimental $(7,21$ e 63 dias). Ao final de cada período, os animais foram mortos, sendo os tubos removidos com o tecido circundante e processados para análise microscópica. As lâminas foram submetidas a análise descritiva e análise semi-quantitativa empregando um sistema de escores de 4 pontos (0-3), a fim de avaliar a formação de fibras colágenas e o infiltrado inflamatório. Os dados obtidos foram submetidos à análise estatística por meio do teste de Kruskal Wallis $(\mu=0,05)$. Os resultados mostraram que não houve diferença estatisticamente significante entre os grupos experimentais e controles, considerando os três períodos de avaliação $(p>0,05)$. As resinas à base de silorane e à base de metacrilato apresentaram resposta tecidual semelhante à do tubo vazio (controle), após implantação no tecido conjuntivo de camundongos isogênicos.

\section{REFERENCES}

1. Brackett MG, Bouillaguet S, Lockwood PE, Rotenberg S, Lewis JB, Messer RLW, Wataha JC. In vitro cytotoxicity of dental composites based on new and traditional polymerization chemistries. J Biomed Mater Res Part B: Appl Biomater 2007;81B:397-402.

2. Chang MC, Chen LI, Chan CP, Lee JJ, Wang TM, Yang TT, et al.. The role of reactive oxygen species and hemeoxygenase- 1 expression in the cytotoxicity, cell cycle alteration and apoptosis of dental pulp cells induced by BisGMA. Biomaterials 2010;31:81648171 .

3. Urcan E, Scherthan H, Styllou M, Haertel U, Hickel R, Reichl FX. Induction of DNA double-strand breaks in primary gingival fibroblasts by exposure to dental resin composites. Biomaterials 2010;31:2010-2014.

4. Wada H, Tarumi H, Imazato S, Narimatsu M, Ebisu S. In vitro estrogenicity of resin composites. J Dent Res 2004;83:222-6.

5. Andersson J, Dahlgren U. Effects on mouse immunity of long-term exposure in vivo to minute amounts of HEMA. Eur J Oral Sci 2011;119:109-114.

6. Krifka S, Petzel C, Hiller KA, Frank EM, Bosl C, Spagnuolo G, et al.. Resin monomer-induced differential activation of MAP kinases and apoptosis in mouse macrophages and human pulp cells. Biomaterials 2010;31:2964-2975.

7. Rakich DR, Wataha JC, Lefebvre CA, Weller RN. Effects of dentin bonding agents on macrophage mitochondrial activity. J Endod 1998;24:528-533.

8. Jontell M, Hanks CT, Bratel J, Bergenholtz G. Effects of unpolymerized resin components on the function of accessory cells derived from the rat incisor pulp. J Dent Res 1995;74:1162-1167.

9. Silva LAB, Freitas AC, Carvalho FK, Queiroz AM, Nelson-Filho P, Porto-Neto ST. Direct pulp capping with a self-etching adhesive system: histopathologic evaluation in dogs' teeth. Oral Surg Oral Med Oral Pathol Oral Radiol Endod 2009;108:e34-e40.

10. Mitra SB, Wu D, Holmes BN. An application of nanotechnology in advanced dental materials. J Amer Dent Assoc 2003;134:13821390 .

11. Weinmann W, Thalacker C, Guggenberger R. Siloranes in dental composites. Dent Mater 2005;21:68-74.

12. Grégoire G, Dabsie F, Delannée M, Akon B, Sharrock P. Water permeability, hybrid layer long-term integrity and reaction mechanism of a two-step adhesive system. J Dent 2010;38:526533.

13. Hahnel S, Henrich A, Bürgers R, Handel G, Rosentritt M. Investigation of mechanical properties of modern dental composites after artificial aging for one year. Oper Dent 2010;35:412-419.

14. Ilie N, Hickel R. Investigations on a methacrylate-based flowable composite based on the SDR ${ }^{\mathrm{TM}}$ technology. Dent Mater 2011;27:348-355.

15. International Standard ISO 10993-6. Biological evaluation of medical devices- Part 6: Tests for local effects after implantation. 1994:1-11.

16. Silva LA, Leonardo MR, Oliveira DS, Silva RA, Queiroz AM, Hernández PG, et al.. Histopathological evaluation of root canal filling materials for primary teeth. Braz Dent J 2010;21:38-45.

17. Krifka S, Seidenader C, Hiller KA, Schmalz G, Schweikl H. Oxidative stress and cytotoxicity generated by dental composites in human pulp cells. Clin Oral Investig 2011 [Epub ahead of print. DOI: 10.1007/s00784-010-0508-5].

Accepted February 23, 2011 